\title{
メニエール病めまい発作期および間欠期の TTS-スコポラミン療法†
}

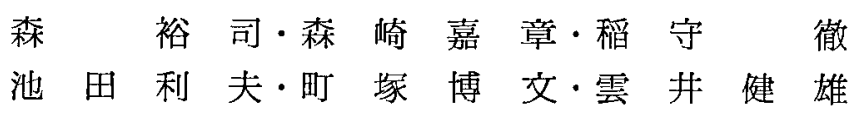

\section{はじめに}

メニエール病患者の眩暈発作及び，それに伴ら瑮心， 咺吐，冷汗などの自律神経症状は，患者にとってはかな りの苦痛であり，またそのために病院を受診できないこ ともしばしばある。このような不快な症状に対して，古 くから動摇病の薬として知られている抗コリン作動性の スコポラミンが，症状軽減の効果があることはよく知ら れている。しかし，その作用持続時間が短いこと，拉よ び副作用の強いことがその普及を妨げていた。この欠点 を補ら投与方法として，最近TTSースコポラミンが開発 された。この投与方法では少量の薬剤を長期間にわたっ て投与することができ，末たその副作用も軽減できるこ

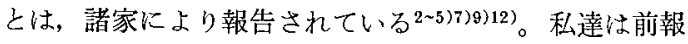
に扣いてTTSースコポラミンをメニェール病患者の発作 直前の時期に貼布させてその有用性, 効果, 副作用, 使 用対象等につき検討した。本報告はこれを受け継いで, メニエール病発作期の成績を補遗するとともに間欠期状 態にある患者に対する効果子試みた。

\section{要 約}

メニエール病に対するTTSースコポラミン（経皮的ス コポラミン製荗）の効果を検討して次の結果を得た。す なわち，メニェール病確実例で，めまい発作の前駆症状 が比較的明らかで，かつ数時間前に患者がそれを自覚で き，また発作時の自律神経症状が強く，また治療に抵抗 する症例では，TTS 製郕を急性発作期の直前に使用す ることは有用な治療法となることが確認されたが，メこ エール病間欠期にある患者では，口渴之の他の副作用が 前景に出現する傾向が強く，その治療効果は顕著でなか った。

$\uparrow$ Transdermal scopolamine in the treatment of acute and intermittent phases of Meniere's disease

Hiroshi Mori, Toru Inamori, Yoshiaki Morisaki, Toshio Ikeda, Hirofumi Machizuka and Takeo Kumoi 兵庫医科大学耳鼻咽喉科学教室

\section{目的亡研究対象}

1986年度の本研究報告 ${ }^{13)}$ にひさついて, メニエール 病確契例に対するTTSースコポラミン経皮片の效果を急 性発作期应例の追加補遺と，新たに発作間欠期にある症 例に対する効果検討をも目的に加えて調查研究を行なっ た。急性期の対象条件は前報と同様で次の如くである。

1. $x=ェ ー ル$ 病確実例。

2. わ発作の前駆症状が比較的明らかで，かつこ れを発作の数時間前に患者が自覚できるるの。

3.內登い発作時の自律神経症状が比較的強いもの。

4.内リンパ水腫を軽減させると思われる治療（イソ ソルビド内服，内リンパ慗開放術など）に抵抗してめま い発作が出現するもの。

間欠期に市るメニエール病患者に対する対象条件

^ニエール病確实例の $5 ち$, 最近 6 力月以上癹作のな い症例で，発作が起こりそうな予感を持つ人々の中で TTS 凧を使用してみたいと申し出たもの。

ただし，以上のらちで急性期の症例については，TTS 郕投与の時点でそれまでに服用していた薬剤は中止して もらい，また間欠期の症例では常用している薬剤があれ ばそれらは継続してもよいこととした。昭和62年1月か 5昭和63年 1 月末むでの間に, 兵庫医科大学耳鼻咽喉科 平衡外来を受診したメニエール病患者のらち, 前述の条 件を満たした21症例に対して TTSースコポラミンの使用 万法，使用上の注意事項などについてよく説明し，使用 パンフレットとともに TTS 剂を交付した。投与方法は 前述の通りで，めまい日誌も手渡した。TTS スコポラ ミンは肌色の阿形のシールでプラスチックフィルムの支 持層，薬物販留層，放出を調整する細孔のある膜，そし て粘着層の 4 層から成る值径 $2.5 \mathrm{~cm}$, 厚さ $0.2 \mathrm{~mm}$ の 貼付剤である。(図 1) 一回の貼付で 3 日間で総量スコ ポラミン $0.5 \mathrm{mg}$ 放出吸收される。今回, TTSースコポ ラミンを投与した症例は，急性期が 12 症例，間欠期が 9 症例の計21例であった。薬剤を貼る部位は一側の耳後部 で（図 2）急性期では前駆症状即ち, 耳閉感, 耳鳴增 


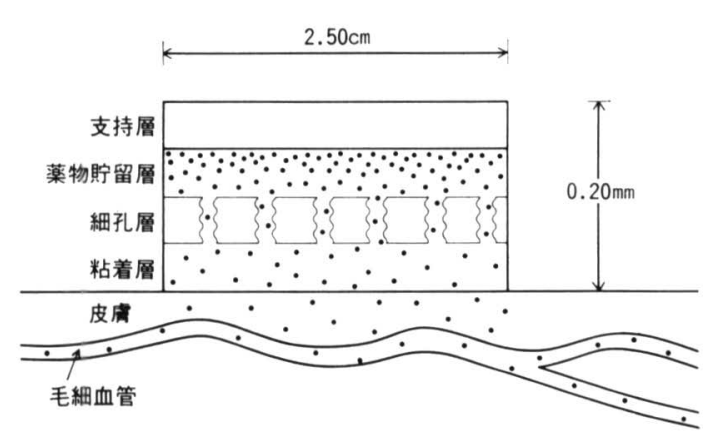

図 1 TTS-スコポラミンの構造

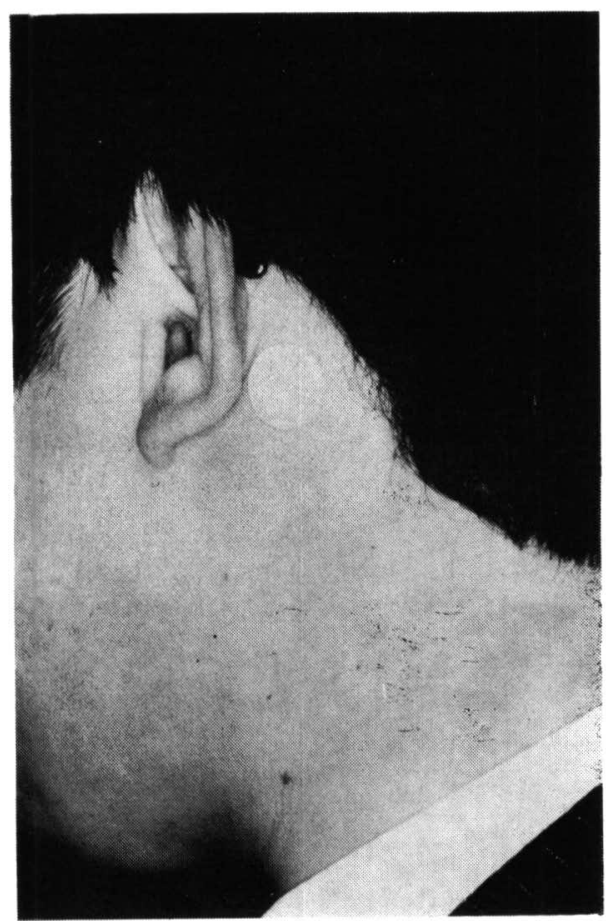

図 2 実際に TTS-スコポラミンを貼付したところ

強が出現した時点で貼るよらに指示し，また間欠期の症 例では 5 日おきに貼り替えるよう指示した。効果判定 は, 自覚的効果判定と他覚的効果判定とで行なった。

\section{結果}

急性期と間欠期との合計の対象症例は男性11名, 女性 10 名, 平均年龄 47.0 才であった。発作期症例（表 1 ）の めまい感は, TTS-スコポラミン貼付によって12症例中 10例は著明に改善し，1 例は軽度改善を示したが，1例 のみ不変であった。難聴と耳鳴とに対しては, 症例 4 で

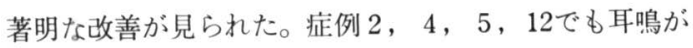
軽度に改善した。自律神経症状に対しては，12例中10例
で著明改善が認められ，1 例は不変であった。他覚的所 見では, 症例 2,12 で聴力の 改善が認められたた程度 で，眼振所見などには特に変化は認められなかった。副 作用に関しては, 眠気が 1 例に軽度認められた。口渴感 は, 症例 $2,9,11$ に強く, 1 例は舌炎をも伴って会話 しにくいと訴えた。他の 3 例にも中等度から軽度の口渴 感を認め, 視覚異常（像がぼやける）は重度 3 例, 軽度 4 例に認めた（表 2 ）。間欠期症例については，(表 3 ， 表 4 ) 耳鳴の軽度改善が 1 例あったのみで殆んどが不変 であった。ただしめまいの予感があってTTSースコポラ ミンを貼付した症例で，めまい発作を抑制し得ず急性発 作をむかえてしまったものはなかった。自律神経検査と して全例にシェロングテストを施行し, 4 例の改善, 1 例 の悪化を認め, その他では大きな変化は認めなかった。 副作用の出現は急性期症例に使用するよりは多い傾向に あった（表 5 ）。

\section{考案}

Belladonna Alkaloid の一種であるスコポラミンは乗 り物酔いの薬として古くから知られていたが, その効果 の持続時間が短いこと及び，十分な効果を長時間得よう とすると用量依存性の副作用が強く出現することから, あまり長期間投与することが困難であり，実用的でない 一面があった。この欠点をカバーするために，簡単な投 与法で長時間一定濃度のスコポラミンを持続投与できる 方法が必要とされていた。この条件を満たす投与方法と して, 最近薬物送達システム (Drug Delivery System, 略して DDS) が考えられ, その応用の一つとして TTS スコポラミンが開発された。TTS スコポラミンは, 耳 後部の皮膚に貼付することによって, 約 $5-6$ 時間後か ら $0.7 \mu \mathrm{g}$ つ’つのスコポラミンを 3 日間放出することが できる。この徐放效果を利用して, TTS スコポラミン は, 多数の科学者達によって, 動摇病の予防に用いられ ている。TTS スコポラミンの効果を検討するために, 被験者に与える刺激として例えば, 航海などの海上生活 (動摇病 $)^{9110)}$, その他の方他としては, 回転刺激を与之 る, カロリックテストを行ならなどによって船酔いに似 た嘔気, 湢吐, 或いはめまいを起こさせることによっ て，その投与前後の差を調べている(2 5)7)12)。その際の客 観的なデータとして眼振を観察しているが，眼振もか なり抑制され，またこれらの検査結果をプラセボ効果 と比較したり，他の薬剤を経口または注射による投与 を行なったものと比較している。これらの研究結果か ら見ると, 同じ抗動摇病薬で経口投与される Dimenhydrinate とほぽ同様の効果を得ることができ，また副作 用の点でも大幅に軽減することができ，持続性において も優れていると述べており，また，局麻剤である Lido- 
表 1 TTS スコポラミンを使用したハニエール鿊例（急性期症例）

\begin{tabular}{|c|c|c|c|c|c|c|c|c|}
\hline 䏠例 & Age & Sex & 患側 & $\begin{array}{l}\text { 雀蚛 } \\
\text { 期間 }\end{array}$ & 発作期間 & 初䛦日 & 治療 & 経 \\
\hline 1 & 56 & 우 & 在 & 14年 & 4 回/作 & S.55.4.14 & $\begin{array}{l}\text { ・イソバイド } \\
\text { ・ボナミンシ } \\
\text { ・ビ夕メジン }\end{array}$ & $\begin{array}{l}\text { S.61作来より } \\
\text { めまい発作頻発 }\end{array}$ \\
\hline 2 & 47 & 우 & 右 & 3 年 & $1 \sim 4$ 日 & S.61.2.17 & $\begin{array}{l}\text { ・イソバイド } \\
\text { ・ボナミン }\end{array}$ & $\begin{array}{l}\text { 治療により } \\
\text { 発作間隔40日 }\end{array}$ \\
\hline 3 & 43 & $\hat{0}$ & 唇 & $\begin{array}{l}2 \text { 尔 } \\
8 \text { 吕月 }\end{array}$ & $2 \sim 3$ 回/月 & S. 61.6 .12 & ・イソバイド & $\begin{array}{l}\text { S.61年11月より } \\
\text { め発作频発 }\end{array}$ \\
\hline 4 & 41 & $\hat{0}$ & 右 & 3 か月 & 5 日 & $\mathrm{S} .61 .12 .16$ & $\begin{array}{l}\text { ・イソパイド } \\
\text { ・メチュバール }\end{array}$ & $\begin{array}{l}\text { 治療にて発作間隔が } \\
\text { 延長 }\end{array}$ \\
\hline 5 & 44 & $\hat{\delta}$ & 相 & 2 年 & $10 \sim 30$ 日 & S.61.2.4 & $\begin{array}{l}\text { ・インバイド } \\
\text { ・コメリアン }\end{array}$ & $\begin{array}{l}\text { 治療により最近は発 } \\
\text { 作問隔 } 3 か \text { 月 }\end{array}$ \\
\hline 6 & 39 & 우 & 有 & 5 年 & 1年 & S. 60.4 .12 & $\begin{array}{l}\text { ・ステロイド } \\
\text { ・ボナミン }\end{array}$ & $\begin{array}{l}\text { S. } 62.3 \text { 月になって } \\
\text { 頻発 }\end{array}$ \\
\hline 7 & 60 & 우 & 有 & 1 年 & $2 か 月$ & S.61.11.11 & $\begin{array}{l}\text { ・イソバイド } \\
\text { ・メチコバール }\end{array}$ & $\begin{array}{l}\text { S.62.1月になって } \\
\text { 頻発 }\end{array}$ \\
\hline 8 & 23 & 오 & 右 & 3 年 & \begin{tabular}{|l|} 
S.54.初期 \\
S.57.よ b \\
Vertigo 頻発 \\
\end{tabular} & S.54.5.1 & $\begin{array}{l}\text { ・メリスロン } \\
\text { ・セファドール } \\
\text { :イソハイド }\end{array}$ & $\begin{array}{l}\text { S. } 62.2 \text { 月より } \\
\text { dizziness }\end{array}$ \\
\hline 9 & 50 & 우 & 在 & 4 年 & $\left|\begin{array}{l}\text { S.58.3力口 月1回 } \\
\text { S.61.より } 1 \text { 回/週 }\end{array}\right|$ & S.62.2.12 & ・イソバイド & S.61.頃上り1回/週 \\
\hline 10 & 38 & $\hat{o}$ & 应 & 2 年 & 1 年 & S.62.4.17 & ・イソバイド & $\begin{array}{l}\text { 治療により } \\
\text { 的い発作減少 }\end{array}$ \\
\hline 11 & 48 & 令 & 右 & 13年 & $\begin{aligned} 1 \text { 午 } \\
1 \\
1 \sim 2 \text { か月 } \\
\end{aligned}$ & S.59.8.14 & $\begin{array}{l}\text { ・カルナクリン } \\
\text { ・イソバイド }\end{array}$ & 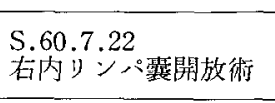 \\
\hline 12 & 51 & 우 & 左 & 5 年 & 2 年 & S. 61.3 .11 & ・イソパイド & 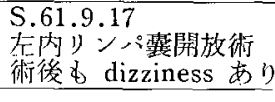 \\
\hline
\end{tabular}

表 2 治療結㤠と副作用（愛性期症例） 絓果 (急性期)

\begin{tabular}{|c|c|c|c|c|c|}
\hline & $\begin{array}{l}\text { め卷 } \\
\text { W感 }\end{array}$ & 菶聴 & 耳鳴 & $\begin{array}{l}\text { 自律神 } \\
\text { 経症状 }\end{array}$ & 他賞的 \\
\hline 著明改善 & 10 & 1 & 0 & 10 & 1 \\
\hline 中等度改善 & 0 & 2 & 1 & 0 & 0 \\
\hline 軽 度 改 善 & 1 & 0 & 3 & 0 & 9 \\
\hline 不 変 & 1 & 9 & 8 & 2 & 2 \\
\hline 悪 & 0 & 0 & 0 & 0 & 0 \\
\hline
\end{tabular}

副作用（急性期）

\begin{tabular}{cc|c|c|c}
\hline & & 眠 気 & 口渴感 & 視覚異栄 \\
\hline 重 & 度 & 0 & 3 & 3 \\
中等度 & 0 & 1 & 0 \\
軽 & 度 & 1 & 3 & 4 \\
諗め ず & 11 & 5 & 5 \\
\hline
\end{tabular}

Equilibrium Res Suppl. 4 caine, tocainide（静脈内投与.) などに比べると嘔気，噪 壮などの自律神経症状及びめまい感を抑制する作用が強 く，長く効果を持続させることができると報告してい $え^{2)}$ 。の結果について, Pyykko $5^{2)}$ は, Scopola. mine, Dimenhydrinate は, 璃幹のある部位 (Shute, Lewis ら によれば脳幹網様体）と，前庭核との間の神 経連絡経路を遮断することによって效果虔表わし, Lidocaine p tocainide の局麻剂は前庭来梢器官機能の抑制 作用を持つとはいいながら，カロリック刺激による眼振 が局麻剤静注によって影響されないことから、テント上 の脳皮質に作用しているのではないかと述へ，動摇病に 対しては無效であったといら。そして Pyykko 详は, 脳幹部と前庭核との間の連絡はコリン作動性に機能して いるらしいから，ここで抗コリン作用をるつスコポラミ ンが抑制效果を示すのであると結論している。Pyyko ら $(1985)^{2)}$ は，16例の volunteer に詨して，力口り\% ク，回転検查，視運動刺激に及法すTTS の効果を調 ベ，TTS-スコポラミンは，1枚㙋る（放出量は $5 \mu \mathrm{g} / 1$ 
表 3 TTSスコポラミンを使用したメニエール症例（間欠期症例）

\begin{tabular}{|c|c|c|c|c|c|c|c|c|}
\hline 症例 & 年 & 性別 & 㭧側 & 罹患期 & 発作間隔 & 初䛦 日 & 治 & 経過 \\
\hline 1 & 71 & $\hat{0}$ & 石 & 6 年 & 3ヶ月 & S.57.12. 2 & $\begin{array}{l}\text { ペルジピン } \\
\text { セロクララール } \\
\text { アバン } \\
\text { カラン }\end{array}$ & $\begin{array}{l}\text { S:60年より } \\
\text { vertigo }(-)\end{array}$ \\
\hline 2 & 45 & $\hat{o}$ & 左 & 3 年 & 2 週 & S.61. 6.12 & $\begin{array}{l}\text { メチュバール } \\
\text { ATP }\end{array}$ & $\begin{array}{l}\text { S. } 61.12 .20 よ り \\
\text { vertigo }(-)\end{array}$ \\
\hline 3 & 62 & 오 & 右 & 2 年 & 3 ケ月 & S.62. 4.10 & $\begin{array}{l}\text { イソバイド } \\
\text { メチコン゙ール } \\
\text { シヒデルゴッ上 }\end{array}$ & $\begin{array}{l}\text { S.62年より } \\
\text { vertigo (一) }\end{array}$ \\
\hline 4 & 52 & 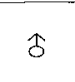 & 兩 & 3年 & 4 ケ月 & S. 62.12 .28 & イソバイド & $\begin{array}{c}2 \text { 年前より } \\
\text { vertigo (一) }\end{array}$ \\
\hline 5 & 37 & 우 & 不 & 2 年 & 1 週 & S.62.11.24 & $\begin{array}{l}\text { イソバイド } \\
\text { メコン゙ール }\end{array}$ & 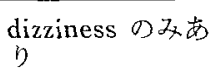 \\
\hline 6 & 59 & 우 & 右 & 20年 & 3ヶ月 & S.61. 8.22 & 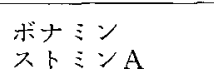 & $\begin{array}{l}\text { S. } 62.8 .6 よ り \\
\text { vertigo }(-)\end{array}$ \\
\hline 7 & 30 & $\hat{\delta}$ & 左 & 1 年 & 6 ケ月 & S.62. 3.18 & イソハイド & $\begin{array}{l}\text { S. } 62.3 .21 よ り \\
\text { vertigo }(-)\end{array}$ \\
\hline 8 & 61 & 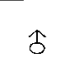 & 左: & 10年 & 2 年 & S.62. 5.20 & $\begin{array}{l}\text { イソパイド } \\
\text { メチェバール }\end{array}$ & $\begin{array}{l}\text { S.62.5月より } \\
\text { vertigo }(-)\end{array}$ \\
\hline 9 & 31 & 今 & 右 & 3 年 & 3年 & S.61.12. 5 & $\begin{array}{l}\text { イソパイド } \\
\text { メコバール }\end{array}$ & $\begin{array}{l}\text { S.61.9月より } \\
\text { vertigo }(-)\end{array}$ \\
\hline
\end{tabular}

表 4 治療結果

\begin{tabular}{|c|c|c|c|c|}
\hline & \multicolumn{2}{|c|}{ 急 性 期 } & \multicolumn{2}{|c|}{ 間 矢期 } \\
\hline & 難聴 & 耳鳴 & 難聴 & 耳鳴 \\
\hline 著明 改善 & 1 & 0 & 0 & 0 \\
\hline 中等度政善 & 2 & 1 & 0 & 0 \\
\hline 軽度改善 & 0 & 3 & 0 & 1 \\
\hline 不変 & 9 & 8 & 9 & 8 \\
\hline 悪 & 0 & 0 & 0 & 0 \\
\hline
\end{tabular}

表 5 副作用

\begin{tabular}{|c|c|c|c|c|c|c|}
\hline & \multicolumn{3}{|c|}{ 急 性 期 } & \multicolumn{3}{|c|}{ 間 次 期 } \\
\hline & 眠気 & 口渴感 & $\begin{array}{l}\text { 視覚 } \\
\text { 異 }\end{array}$ & 眠気 & 口潟感 & $\begin{array}{l}\text { 視賞 } \\
\text { 異 }\end{array}$ \\
\hline 重度 & 0 & 3 & 3 & 0 & 0 & 0 \\
\hline 中等度 & 0 & 1 & 0 & 0 & 4 & 0 \\
\hline 軽 度 & 1 & 3 & 4 & 1 & 0 & 1 \\
\hline 劷めず & 11 & 5 & 5 & 8 & 5 & 8 \\
\hline
\end{tabular}

時間)よりも， 2 枚 (放出量は $10 \mu \mathrm{g} / 1$ 時間) 貼ったほ らが，著明な效果を得ることができ， Dimenhydrinate より有意に，カロリックテストにより誘発される嘔気， 嘔叶，眩簐さ抑制することができるが，1枚の TTS-ス
コポラミンでは, Dimenhydrinate よりる效果が劣るこ とを示寸報告を行なっている334)。乙の報告では,カロリ ックテストによって誘発された眼振の最大緩徐相速度は TTS 貼付によって有意に低下するが，眼振の頻度には 有意差がなく，回転検査ではTTSースュポラミン 2 枚と Dimenhydrinate で㤝有意に前庭系の反忘が低下するが， 1 枚の TTSースコポラミンでは有意差がなく, Optokinetic nystagmus でも2 枚の TTS-スコポラミンのみが 有意に反灾を抑制したと述べている。これらの結果から Pyykko らは, TTS スコポラミンの標的部位は前庭神 経核であるらとし，前庭系と視覚系入力とが泥在してい る統合部を抑制することによってTTSースコポラミンや Dimenhydrinate が動摇病の症状を抑制するのではない かと結論し，前庭系の興舊の抑制と同样に視覚入力の抑 制も大切な効果であると報告している。これらの報告の 事実からメニエール病の特に発作期の患者に対する私達 の使用経験に扣いて自律神経症状を抑制できた事は，ス コポラミンの直接的な薬效のみならず，発作期のめ季い 自体をも軽減できたのは，前庭核から脳幹部への連絡を 遮断（これはカロリックテストでの緩徐相速度の減少す る事実で理解できる)，視運動性眼振の抑制効果を示した 実験より考えて，視性入力と前庭入力との統合部である 前庭神経核の抑制によってめまいを軽くすることができ たのであろうと類推される。また使用枚数についていえ 
ば, 彼らの用いた TTS 剂の量は, 私達の用いた量 ( 3 日間 $0.5 \mathrm{mg}$, 約 $7 \mu \mathrm{g} / 1$ 時間) 甠彼らの用いた 1 枚 (5 $\mu \mathrm{g} / 1$ 時間 $) と(10 \mu \mathrm{g} / 1$ 時間 $)$ との中間位にあり, 欧米 人との体格の違いも考虑したらえで, 私たらのメニエー ル病に対する投与経験では 1 枚の TTS で十分な効果を 得ることができると考えているが，むし1枚で十分な効 果が得られない場合は副作用の出現状態注意しながら 増量しても良いのではないかと考光ている。Robert Mayer $5^{(6)}$ 性抗癌化学療法後（例光ば CDDP ば゙）の嘔 気, 嘔吐に対してTTS-スコポラミンを使用し, その作 用は，孤束核，蝸牛，迷走神経，などのコリン作動性或 るいは，ヒスタミン作動性の部分に作用するのではない かと述べて㧊り，制吐作用としても十分に効果があると 結論している。Joseph ${ }^{11}$, Bruce ら ${ }^{8)}$ は TTS-スコポ ラミンの副作用について，体重に対しての投与量の関係 のみではなく, 子供に投与する際に性細心の注意が必要 で，精神的な副作用例点ば失見当識なども可这性ではあ るが存在すると注意を呼びかけている。

TTSースコポラミンの効果持続時間については, W. F.

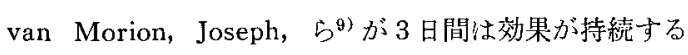
が，強い效果は，最初の 2 日間であると述べて括り強い 自律神経症状を示している患者に対しては 2 日ごとに貼 り替えるほらが良いのではないかと考えられる。

最後に TTSースコポラミンを使用できない人はスコポ ラミンに対する薬物過敏性のある人, 奼婦, 高血压の人 達で，子供に投与するときは十分な注意を要することを 付け加光たい。

\section{まとめ}

メニエール病患者に詨してTTSといら方法を使って スコポラミンを投与する機会を得た。今回 TTSースコポ ラミンを投与した症例は, 急性期が12症例, 間欠期が 9 症例の計21例であった。急性期の強い自律神経症状小よ び，めまい感を12例中10例で抑觉ることができた。スコ ポラミンの強い副交感嗻断作用はメニェール病発作期の 自律神経症状を軽減または消失させることによって，患 者の不安感の軽減に対して非常に有用であった。同時 に，耳鳴，難聴なども軽減する例が認められた。たと党 めまい発作が起こったあとに使用してる，嘔気や悪心な どを鎮静する効果がありまた前庭迷路系と中权神経系と の連絡経路を遮断することによって自律神経症状のみな らず，めまい感やめまい発作さ兄す軽減させることがで きるといらことが確かめられた。TTS という微量持続 的製凨投与の応用によって，スコポラミン自身の副作用 の程度も全般的に軽減させることができたが，1例のみ は強度の口渴と, それに伴う舌炎を起こした。ただし， 間欠期の患者では，発作期の患者代刘する注ど著明な効
果はなく，副作用は強いよらに思われる。これは急性期 の患者では, 発作時の強い自律神経症状のために, 副作 用としての口渴感，羞明などがあまり気にかからない が，間欠期の患者では副作用が冷静代評価されるためと 思われた。以上の結果から，TTS の使用上の適応は， 前駆症状が比較的はっきりしていて自律神経症状の強い 患者に使うのが良いと考えた。

尚, 本研究は厚生省特定疾患前庭機能異常調查研究班 の研究費援助に上り行われたものである。

\section{文献}

1) Scute CC, Lewis PR : Cholinesterase containing pathways of the brain of the rat. Neture 199 : 1160-1164, 1963

2) Pyykko I, Padoan S: The effect of TTS-Scoporamine. Dimenhydrinate. Lidocaine, and Tocainide on Motion Sickness. Vertigo, and Nystagmus, Aviation. Space, and Environmental Medicine $56: 777-782,1985$

3) Pyykko I, Schlen L : Transdermally Administered scopolamine vs. dimenhydrinate I. Effect on nausea and vertigo in experimentally induced motion sickness : Acta Otolaryngol (Stockh) 99 : 588-596, 1985

4) Pyykko I, Schlen L : Transdermally Administered scopolamine vs. dimenhydrinate II. Effect on different types of nystagmus. Acta Otolaryngol (Stockh) $99: 597-604,1985$

5) Pyykko I, Schlen L : Reduction of Vestibulovisual integration during transdermally administerd scopolamine and dimenhydrinate. Acta Otolaryngol (Stockh) Suppl. 406:167-173, 1984

6) Mayer BR, O'Mara V : A Controled clinical ttial of the addition of transdermal scopolamine to a standard metoclopramide and dexamethasone antiemetic regimen.: J Clinical Oncology 5: 1994-1997, 1987

7) Graybiel A, Cramer DB : Antimotion-sickness efficacy of scopolamine 12 and 72 hours after transdermal administration. Aviat Space Environment Med 53:770-772, 1982

8) Klein BL, Ashenburg CA : Transdermal scopolamine intoxication in a child. Pediatric Emargency Care 1:208-209, 1985

9) Marion WF, Bongaerts MCM : Influence of transdermal scopolamine on motion-sickness during 7 days' exposure to heavy seas. Clin 
Pharmacol Ther $38: 301-305,1985$

10) Gordon AJ, Ribak C : Efficacy of transdermal scopolamine against seasickness : A 3-day study at sea. Aviat Space Environ Med 58 : 60-62, 1987

11) Wilkinson JA : Side Effect of transdermal scopplamine. J Energ Med 5 : 389-392, 1987

12) Schmitt LG, Shaw JE : Alleviation of induced vertigo. Ach Otolaryngol Head Neck Surg 112 : $88-91,1986$

13）雲井健雄：メニエール病のめまい発作期における TTSースコポラミンの使用検討. Equilibrium Res Suppl $2: 126-129,1987$

\section{Abstract}

The efficacy of transdermal scopolamine (TTSscopolamine) was evaluated in 21 patients, 10 females and 11 males, with confirmed Meniere's disease. Twelve patients in the acute phase who could recognize relatively definite prodromal symptoms, such as a sensation of ear fullness and/or tinnitus, etc., several hours before the onset of intractable vertigo accompanied by severe autonomic nerve disturbances and nine patients in the intermittent phase were included in this study. For the acute phase patients, one sheet of TTS scopolamine (TTS 1.5) $(7 \mu \mathrm{g} / \mathrm{h}$ release) was prescribed for application to the postauri- cular skin to be left for three days when the prodromal symptoms occurred. In the intermittent phase patients, one sheet of TTS scopolamine was applied as indicated.

TTS scopolamine significantly reduced vertigo and autonomic nervous symptoms (nausea, vomiting) in 10 of the 12 acute phase patients. In the intermittent phase patients, tinnitus and hearing loss were vertually unchanged by TTS-scopolamine application. TTS-scopolamine, with scopolamine released for up to 3 days, generally did not cause scopolamine's usual side effects, such as drowsiness and sedation, but minor reactions of blurred vision and dry mouth were observed.

In conclusion, our objective in the present study was to evaluate TTS-scopolamine efficacy and its side effects in the treatment of attacks of Meniere's disease. In acute phase patients, TTS provided satisfactory relief and the side effects were minor and tolerable.

Key words: TTS-scopolamine, Meniere's disease

$\left(\begin{array}{l}\text { 原稿到着 : 昭和63年 } 3 \text { 月 } 31 \text { 日 } \\ \text { 別刷請求先 : 森 裕司 } \\ \text { 个663 西宫市武庫川町 } 1-1 \\ \text { 兵庫医科大学耳鼻咽㩔科学教室 }\end{array}\right)$

